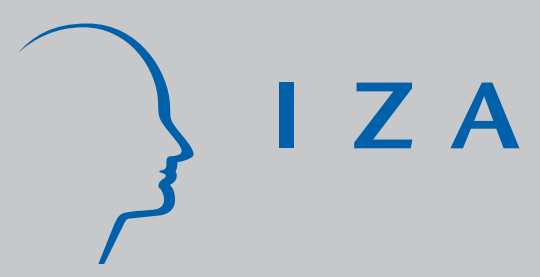

IZADP No. 2683

The Labour Market Position of Turkish Immigrants in Germany and the Netherlands: Reason for Migration, Naturalisation and Language Proficiency

Rob Euwals J aco Dagevos Mérove Gijsberts

Hans Roodenburg

March 2007 


\title{
The Labour Market Position of Turkish Immigrants in Germany and the Netherlands: Reason for Migration, Naturalisation and Language Proficiency
}

\author{
Rob Euwals \\ $C P B$, The Hague, \\ Netspar and IZA \\ Jaco Dagevos \\ SCP, The Hague \\ Mérove Gijsberts \\ SCP, The Hague \\ Hans Roodenburg \\ $C P B$, The Hague
}

Discussion Paper No. 2683

March 2007

\author{
IZA \\ P.O. Box 7240 \\ 53072 Bonn \\ Germany \\ Phone: +49-228-3894-0 \\ Fax: +49-228-3894-180 \\ E-mail: iza@iza.org
}

\begin{abstract}
Any opinions expressed here are those of the author(s) and not those of the institute. Research disseminated by IZA may include views on policy, but the institute itself takes no institutional policy positions.

The Institute for the Study of Labor (IZA) in Bonn is a local and virtual international research center and a place of communication between science, politics and business. IZA is an independent nonprofit company supported by Deutsche Post World Net. The center is associated with the University of Bonn and offers a stimulating research environment through its research networks, research support, and visitors and doctoral programs. IZA engages in (i) original and internationally competitive research in all fields of labor economics, (ii) development of policy concepts, and (iii) dissemination of research results and concepts to the interested public.
\end{abstract}

IZA Discussion Papers often represent preliminary work and are circulated to encourage discussion. Citation of such a paper should account for its provisional character. A revised version may be available directly from the author. 


\section{ABSTRACT}

\section{The Labour Market Position of Turkish Immigrants in Germany and the Netherlands: Reason for Migration, Naturalisation and Language Proficiency ${ }^{\star}$}

On the basis of the German Socio-Economic Panel 2002 and the Dutch Social Position and Use of Provision Survey 2002, we investigate the importance of characteristics related to immigration for the labour market position of Turkish immigrants. We use regression techniques to correct for composition effects in employment rates, tenured job rates and job prestige scores (ISEI). First, we find that educational attainment and language proficiency have a higher return in the Netherlands than in Germany. Second, we find that second generation immigrants have improved their labour market position relative to the first generation of labour migrants and their partners. The improvement is largely due to an improvement in educational attainment and language proficiency. Third, for the Netherlands we find a positive relation between naturalisation and labour market position, while for Germany we find a negative relation with tenured employment. The contrasting results on tenured employment may be explained partly by differences in immigration rules. In Germany economic self-reliance is more important than in the Netherlands, and this may lead to a stronger incentive to naturalise for workers with a temporary contract.

JEL Classification: $\quad$ C25, F22, J15, J61

Keywords: immigration, labour market, naturalisation, language proficiency

Corresponding author:

Rob Euwals

CPB Netherlands Bureau for Economic Policy Analysis

P.O. Box 80510

2508 GM Den Haag

The Netherlands

E-mail: r.w.euwals@cpb.nl

\footnotetext{
* The authors thank Pieter Bevelander, Amelia Constant, Sjef Ederveen, Han Entzinger, Joachim Frick, John Haisken-DeNew, Holger Hinte, Michael Fertig, Pierre Koning, Peter Kooiman, Ruud Koopmans, Aslan Zorlu and participants at the SOEP User Conference 2006 and seminars at CPB, IZA and RWI Essen for comments and suggestions. The provision of data by DIW Berlin and Statistics Netherlands is acknowledged. The paper is the result of a joint CPB-SCP research project which led to the Dutch publication Dagevos et al. (2006).
} 
Immigration policy and the integration of ethnic minorities are hotly debated in many countries, including Germany and the Netherlands. International comparisons of the labour market position of immigrants are interesting as one may learn from different policies in different countries. Comparisons between countries are however difficult for at least two reasons. First, countries use different definitions for immigrants. Second, countries attract different immigrants from different countries. This study overcomes such measurement problems by using survey data and by applying one definition of an immigrant to individuals from one country of origin. The study investigates the relation between individual characteristics related to immigration and the labour market position. The immigration characteristics include reason for migration, naturalisation and language proficiency, while the labour market outcomes include employment rates, tenured job rates and job prestige scores (ISEI).

By comparing immigrants from the same country of origin, so with a similar social and cultural background, in two host countries we hope to learn about the relevance of immigration and integration policies. The comparison of Turkish immigrants in Germany and the Netherlands is interesting because of two aspects. First, the Turks are a major immigrant group in both countries, in particular as both countries recruited substantial numbers of so-called 'guest workers' from Turkey in the 1960s and early 1970s. Second, while both countries have labour market institutions that are similar in many aspects, the countries followed rather different immigration, naturalisation and integration policies. For example, Germany followed a remigration policy in 1983 and 1984, while the Netherlands never followed such a policy. And Germany was restraint in offering German nationality, while the Netherlands offered easy access to Dutch nationality. Of course, our research method has drawbacks as well. In particular we do not know whether our results can be generalized to other countries and other immigrant groups. We therefore need be careful with generalizing our results.

The comparison of labour market outcomes of immigrants with a similar background between host countries is a challenging research approach, used by several other authors. Model et al. (1999) find no substantial differences in the labour market position of black Caribbean migrants in France, Canada, the UK and the US, while Kogan (2003) finds that ex-Yugoslavs fare better in Austria than in Sweden and Lewin-Epstein et al. (2003) find differences for immigrants from the former Soviet Union: they fare better in Canada than in Israel. The latter study relates these outcomes to the explicit selection of the Canadian point system and the integration policy of Israel. Ancetol et al. (2003) compare immigrants to Australia, Canada and the US, and conclude that skills of immigrants are largely explained by country of origin. Using individual level data from 18 host countries for 187 different immigrant groups, Tubergen et al. (2004) find as well 
that country of origin is important and that countries with a so-called point system do not achieve better labour market outcomes for immigrants of a given country of origin. Constant and Schultz-Nielsen (2004) compare immigrants in Germany and Denmark and conclude that in both countries second generation non-Western immigrants do better on the labour market than the first generation. Furthermore, immigration characteristics like language proficiency and country of schooling do matter for earnings. Büchel and Frick $(2004,2005)$ investigate the relative income position of immigrants in several European countries and find that the outcomes differ substantially between countries, even when controlling in detail for social structure and the level of integration. Boeri (2006) finds that after correction for individual labour market characteristics immigrants in several European countries do not have a larger probability than natives to be dependent on social welfare.

In this study, we use two micro datasets to investigate the labour market position of Turkish immigrants in the year 2002: the German Socio-Economic Panel, and the Dutch Social Position and Use of Provisions Survey. We use regression techniques to correct for composition effects in the employment rates, tenured job rates and job prestige scores (ISEI, which is a measure for the relative job position on a scale from 10 (low) to 90 (high)). First, we find that educational attainment and language proficiency have a higher return in the Netherlands than in Germany. Second, we find that second generation immigrants have improved their labour market position relative to the first generation of labour migrants and their partners. The improvement is largely due to the improvement in educational attainment and language proficiency of the second generation relative to the first generation. This holds for both countries, whereby there are important differences between the countries due to differences in the return to education and language proficiency. Third, for the Netherlands we find a positive relation between naturalisation and labour market position, while for Germany we find a negative relation with tenured employment. The contrasting results on tenured employment may be explained partly by differences in immigration rules. Economic self-reliance plays a more important role in the German immigration procedures, and this may lead to a stronger incentive to naturalise for at least some workers with a temporary contract.

The remainder of the study is organized as follows. First of all, section 2 discusses the literature on reason for migration, naturalisation and language proficiency. Section 3 discusses the history of Turkish immigration into Germany and the Netherlands. Section 4 introduces the data we use in this study, while Section 5 presents the empirical results on the basis of these data. Section 6 concludes. 


\section{$2 \quad$ Literature}

This section discusses studies on the role of reason for migration, naturalisation and language proficiency for the labour market position. We take a particular interest in studies on Germany and the Netherlands. In such studies the Turkish immigrants are always a major group as they are the largest immigrant group in both countries. Note that of course many other aspects are important for the labour market position of immigrants, including educational attainment, immigration and integration policy, and labour market and social security policy. These aspects are addressed in two accompanying studies (Dagevos et al., 2006a, Euwals et al., 2006), and they are therefore beyond the scope of current study.

\section{$2.1 \quad$ Reason for migration}

The current literature on reason for migration and labour market position consists of two major parts: one part discusses the labour market performance of labour migrants, while another part discusses the integration of second generation immigrants. As labour migrants are generally young and well motivated to work, their performance on a host country's labour market may be expected to be good in the first years after arrival. The labour migrants in this study, the first generation Turks which came to Europe to work, are however low-skilled. An important part of the policy discussion in both countries is directed towards the integration of family reunification and family formation immigrants, and in particular second generation immigrants.

Labour migrants potentially contribute to the economy of a host country: they are mostly young and well-motivated to work. A part of the economics literature on immigration discusses the self-selection of immigrants and the role of selective immigration policies. For example, Chiswick $(1978,1999)$ argues that labour migrants are positively self-selected. Several authors argue however against positive self-selection, whereby Dustmann (1993) uses Chiswick's model to show that under certain conditions immigrants will be self-selected negatively. The role of immigration policy is heavily discussed as well: Antecol et al. (2003) compare the policies of Australia, Canada and the US, while Constant and Zimmermann (2005) take a European perspective and emphasize the advantages of a selective policy. The labour migration in the current study was however not the result of a selective immigration policy, and the labour migrants were low-skilled. And although their employment rates were close to 100 percent upon arrival, their labour market performance has deteriorated over time. This is particularly true for the Netherlands (see, for example, Van Ours and Veenman, 2005).

Do second generation immigrants and first generation immigrants that arrive at child age integrate into society? In both Germany and the Netherlands the first generation Turkish labour 
migrants were followed by their family, and their children are currently reaching working age. In both countries second generation immigrants have a lower educational attainment than native youth. While Gang and Zimmermann (2000) find second generation immigrants to be closing part of the gap with their natives counterparts on the basis of the German Socio-Economic Panel, Riphahn (2003) finds no such evidence on the basis of the German Census. Van Ours and Veenman (2003) do find a closing of the gap for the Netherlands. But in terms of the labour market position, Van Ours and Veenman (2004) find that in particular Turkish and Moroccan youth have low employment rates relative to their native counterparts.

\section{$2.2 \quad$ Naturalisation}

The relation between naturalisation, integration and labour market performance is complex. On the one hand naturalisation may be viewed as an outcome of successful integration, while on the other hand naturalisation may be part of the integration process which contributes to a successful labour market performance. Causal relations are therefore difficult - maybe even impossible - to identify. In this study we will therefore at best conclude that naturalisation and labour market position are related to each other.

Most of the traditional literature on naturalisation focuses on the influence of integration into the host country on their acquisition of naturalisation (see Yang, 1994, for an overview). The literature stresses the role of socioeconomic and cultural achievements as well as demographic characteristics. Individual immigrant characteristics and achievements are used to predict naturalisation, and causality is assumed to go from labour market position to naturalisation.

More recent studies consider naturalisation as a means of integration, and in particular of socioeconomic and labour market integration. In particular the impact of naturalisation on wages (Bratsberg et al., 2002, Devoretz and Pivnenko, 2006) and the incidence of employment (Bevelander and Veenman, 2006a, 2006b, Fougère and Safi, 2006) are subject of study. The underlying idea is that the incidence of naturalisation is based on an individual cost/benefit analysis. Causality is assumed to go from naturalisation to socioeconomic integration and labour market position.

In both Germany and the Netherlands, benefits of citizenship includes political privileges like the right to vote, civil rights like the formal right to equal treatment, and access to jobs for civil servants (which may be more important in Germany than in the Netherlands). ${ }^{2}$ Furthermore,

\footnotetext{
${ }^{2}$ For details on the naturalisation procedures and the accompanying costs and benefits in Germany and the Netherlands, see studies like DeVoretz et al. (2002), Diehl and Blohm (2003), and Bevelander and Veenman (2006a, 2006b).
} 
deportation as an undesirable alien is impossible for citizens, which in recent years has proven to be an issue in exceptional cases in both countries. Costs of naturalisation include direct costs, including fees, foregone time and stress, but they also include opportunity costs due to loosing citizens rights in the home country. The latter aspect may be of importance for this study, as Germany does not allow for double citizenship while the Netherlands did during the 1990s.

Recent studies on naturalisation of guest workers in Germany and the Netherlands argue that naturalisation and integration should be positively related. Diehl and Blom (2003) conclude that legal advantages are too small to explain naturalisation in Germany. Instead, they claim that in particular Turks who achieved a high level of individual assimilation choose for naturalisation to achieve individual upward mobility and to improve their position within society. The authors compare Turkish to (former) Yugoslavian immigrants, and conclude that the Yugoslavians rarely choose for naturalisation as their reasonable social status makes naturalisation unnecessary for upward individual mobility. So although naturalisation is associated with integration, it is the group with a relatively low social status - the Turks - that chooses for naturalisation. Bevelander and Veenman (2006a, 2006b) take a cost/benefit perspective on naturalisation, and find contrasting results on the relation between naturalisation and labour market position: while the first study reports the existence of a positive relation between naturalisation and labour market position, the second study finds a positive relation for Turkish women and a negative relation for Turkish men.

\subsection{Language proficiency}

An important aspect of integration into a host country is the acquisition of the host country's language. Besides it's role in social and cultural integration, the importance for economic and labour market integration is without doubt. Many studies for different countries show that language proficiency and labour market performance, i.e. wages and employment, are strongly related to each other. Although the causal impact of language proficiency on wages is in fact not straightforward to identify, recent studies show that standard regression methods (which will be used in this study) lead to an underestimation of the true impact of language.

The importance of language proficiency for wages became subject of empirical research in the US at the beginning of the 1980s. ${ }^{3}$ For Europe, most of the research is on Germany (Dustmann, 1994, 1999) and the UK (Shields and Wheatly Price, 2002, Dustmann and Fabbri, 2003). The studies explain wages from language proficiency, and almost without exception they find

\footnotetext{
${ }^{3}$ See Carliner (1980), McManus et al. (1983) and Grenier (1984). The dispute on the integration of immigrants in the US (Chiswick, 1978, Borjas, 1985) played an important role in the development of this literarure.
} 
language proficiency to be important. Whether the evidence is to be interpreted as a causal impact remains open as selection and reversed causality may play a role. For example, being employed may give immigrants the opportunity to improve their language proficiency. Recent studies that correct for different kinds of endogeneity (Chiswick and Miller, 1995, Dustmann and Van Soest, 2001, 2002) however find that standard regression methods actually tend to underestimate the true causal impact. So results from standard regression methods may be interpreted as an underbound for true causal impact.

While for Germany there is a rather substantial number of studies on language proficiency (see the references above), the number of international studies for the Netherlands is limited. Florax et al. (2003) study the role of segregation and networking for language acquisition, but they do not investigate the impact on labour market outcomes. Publications in Dutch generally find that language proficiency is related to labour market position (see, for example, Dagevos, 2003, and Dagevos et al., 2006b).

\section{Turkish immigrants in Germany and the Netherlands}

Both Germany and the Netherlands started to recruit substantial numbers of so-called 'guest workers' from Turkey from the middle of the 1960s on. Nowadays, the Turks are one of the major immigrant groups in both countries. At the end of 2003, about 1880000 persons with Turkish nationality lived in Germany. This is about $2.3 \%$ of the German population and $2.8 \%$ of the population of the West German states (where they live). At January 1, 2004, about 350000 first and second generation Turks lived in the Netherlands. This is about 2.2\% of the Dutch population. As the German figure does not include Turks which switched to German nationality, Germany clearly hosts relatively more Turkish immigrants than the Netherlands.

The statistical offices of both countries use different definitions of immigrants, and a direct comparison of national statistics is therefore problematic. While the German definition is based on nationality, the Dutch definition of 'allochthonous' people is based on country of birth of an individual and the individual's parents. The Dutch 'allochthonous' people are first and second generation immigrants, and in the international literature this is a rather common definition. In the empirical part of this study we will therefore use the latter definition, also for Germany as the German survey data contain all relevant information. The current chapter will discuss the history of Turkish immigrants on the basis of the official statistics of both countries. As in Germany the number of naturalisations was limited until the middle of the 1990s, the official data is reasonably comparable between the countries until that time. 


\subsection{Immigration and remigration policy}

Both Germany and the Netherlands went through a long period of economic growth during the 1960 s, and the number of Turkish immigrants started to grow strongly from the end of the 1960s onwards (figure 3.1). The first oil crisis was the end of the official recruitment of Turkish guest workers, and the number of entrants decreased. For Germany the lower growth of the number of immigrants was temporary, and the number of new entrants again peaked in the 1980s. The second oil crisis resulted into an economic crisis, and long-term unemployment became a serious problem. From that moment on migration from Turkey almost exclusively existed of family and asylum migration. Immigration and remigration policy started to develop differently between the countries. While until that time Turkish guest workers were viewed to be temporary immigrants, the Dutch government started to change its view on the temporary aspect during the 1980s. It took until the end of the 1990s before the German government changed its view as well. Below we discuss three important differences in policy.

\section{Figure 3.1 Turkish immigrants as a fraction of the population, 1967-2004}

$\%$

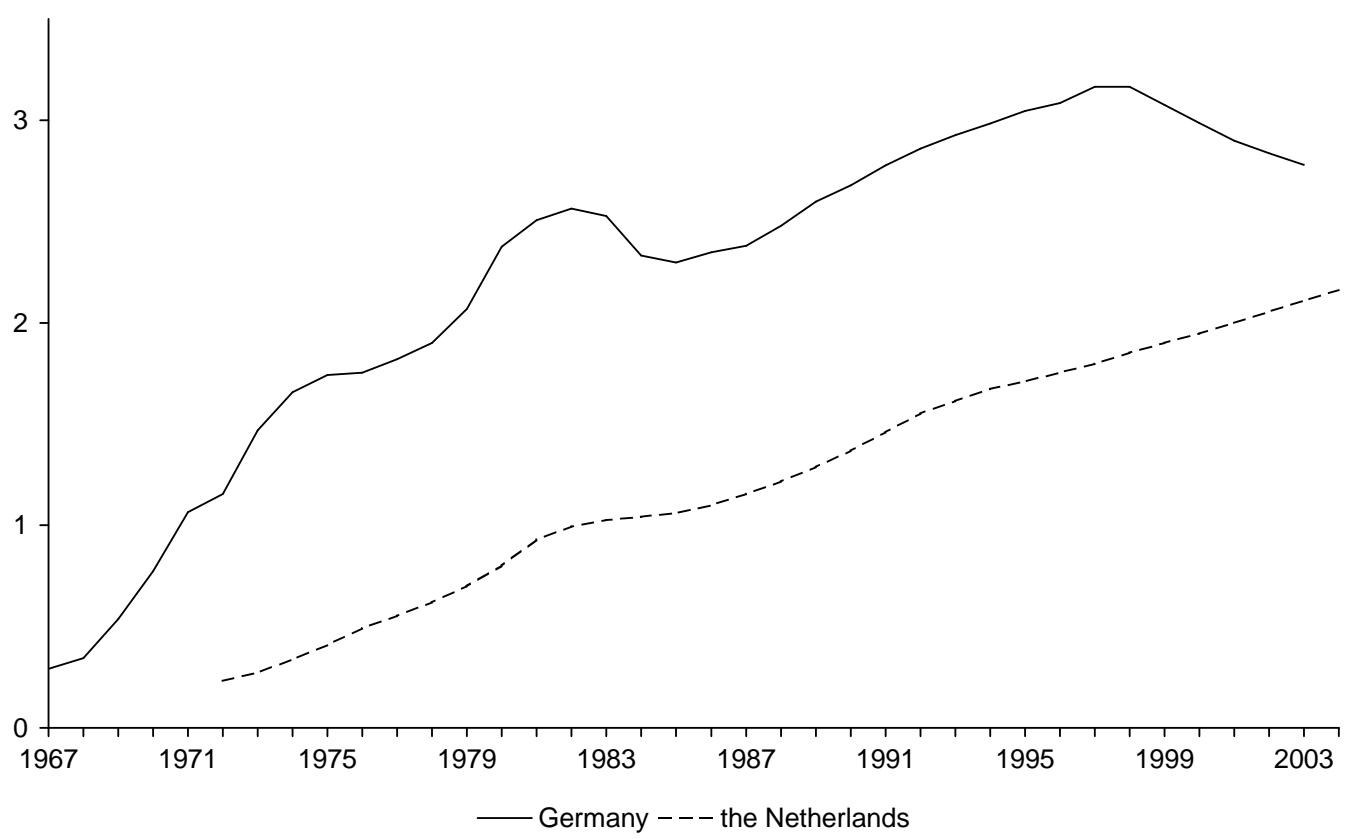

${ }^{a}$ The German definition of a Turkish immigrant is based on nationality, while the Dutch definition is based on the country of birth of an individual and the individual's parents.

Source: Eurostat, Statistics Germany, Statistics Netherlands.

A first difference between the countries concerns the requirements for a permanent residency permit. In Germany, immigrants could apply for such a permit after eight years of stay and were 
required to prove to be economically self-reliant. In the Netherlands, the term was five years and requirements with respect to economic self-reliance were in practice more lenient.

A second major difference was in family reunification and formation policy. While the German policy was restrictive as employment and income conditions were imposed, the Dutch policy was more liberal. So although the recruitment of guest workers had stopped in 1980s, the number of Turkish immigrants living in the Netherlands continued growing (figure 3.1). In the first years this was mainly due to family reunification, but later on family formation became important as the children of the guest workers often married persons from their parents' country of birth. In Germany immigration continued as well, but asylum immigration played a much more important role leading to more skilled immigration. Recently, both Germany and the Netherlands reviewed their policy such that they became more similar: while Germany became less restrictive with respect to family reunification and family formation, the Netherlands became more restrictive. The impact of the most recent policy changes is however hardly visible in figure 3.1 as the policy changes were installed by the beginning of the new century.

A third major difference between the countries was in remigration policy. While Germany followed an active remigration policy in 1983 and 1984, the Netherlands never installed such a policy. The result of the policy is visible in figure 3.1: in those years the number of Turkish immigrants living in Germany decreased, and in 1984 more than 200000 Turks left Germany.

A last fact that is clearly visible from figure 3.1 is a decrease in the number of individuals with Turkish nationality living in Germany since the end of the 1990s. This is clearly not related to remigration: they still live in Germany but changed to German nationality which became easier due to a change in naturalisation policy.

\subsection{Naturalisation policy}

The difference in the official view on the temporary residency of the guest workers led to a difference in naturalisation policy between the two countries. ${ }^{4}$ German naturalisation policy was based on the principle of jus sanguinis, implying that German nationality is difficult to acquire without German ancestors. As guest workers were considered to be temporary labour migrants naturalisation policy was not an issue. Not earlier than from July 1, 1993, onwards new legislation allowed first (second) generation immigrants to acquire German nationality after a residency period of 15 (8) years. From 2000 on the residency period became 8 years for first

\footnotetext{
${ }^{4}$ For a detailed description of the German naturalization policy, see for example Diehl and Blom (2003), while for the Netherlands, see for example Bevelander and Veenman (2006a, 2006b).
} 
generation immigrants while second generation immigrants could opt for German nationality at reaching maturity (leaving the principle of jus sanguinis for second generation immigrants).

The number of naturalisations increased strongly, reached a maximum of about 100000 in 1999 and the number became 50000 in the years afterwards.

Dutch nationality is relatively easy to acquire for immigrants as the necessary residency period is rather short (3 to 5 years). Second generation immigrants with both parents non-Dutch can opt for citizenship when they become mature and have lived their whole life in the country. Moreover, from 1992 until 1997 immigrants could have a double citizenship by keeping their original nationality. This lead to a peak in the number of naturalisation in 1996 and 1997. And although after 1997 immigrants were allowed to have one nationality only, many Turkish immigrants were exempted from this regulation. From 2003 onwards Dutch naturalisation policy started to become more strict as an immigrant needs to pass a test to acquire the Dutch nationality.

\subsection{Integration policy}

Like naturalisation policy, integration policy was not an issue in Germany for a long time as permanent immigrants were supposed to assimilate, while the Netherlands has implemented integration policies from the 1980s onwards. Integration policies were minimal in Germany for many years. Not earlier than during the 1990s, job training and linguistic skill schemes were installed to help second generation immigrants to find employment. The OECD (1998) reports that in recent years some 1800 young foreigners benefited from the training schemes, whereby one should keep mind that the population of foreigners was about several millions. German authorities viewed more general policy measures as more important, and for example general schooling was seen as the major way to integrate. The drop out rates of foreign children dropped substantially during the 1980s and 1990s, but nevertheless the difference with native children remains large (OECD, 2006).

In the Netherlands, integration policies began to soar during the 1980s. Until recently the policy encouraged immigrants to preserve their own cultural identity. For instance, children received part of their lessons in their own language and culture during school hours, and organisations of ethnic minorities received subsidies. Cultural diversity was highly valued, and while immigrants should integrate their own cultural identity should be preserved at the same time. The Netherlands shared this view on integration policy with countries like the U.K. and Sweden, and it clearly contrasts with the view of the German or, for example, the French policy (see section 2.1 as well). 
In recent years, the German and Dutch policy started to become more similar. In 1998, the socalled 'inburgering' programme was introduced in the Netherlands. This programme, which includes a Dutch language course, an introduction to Dutch institutions and values, and labour market orientation, is considered to be the first step towards integration. Participation is planned to be compulsory for new immigrants. The successful completion of the programme will then be required for those who want to obtain a permanent residence permit or Dutch nationality. So while the old Dutch approach could be characterized as 'support-oriented', the new approach may be characterized as 'incentive-oriented'. The new approach draws international attention, and currently Germany has started to introduce similar programmes.

Our study deals with data on immigrant populations up till the year 2002. This means that the vast majority of immigrants involved will not have been affected by the recent changes in integration policies. So, for our study only the old regimes are relevant. And the old regimes differed substantially as Germany expected immigrants to assimilate which was supposed to be their own responsibility, while the Netherlands installed integration policies which supported cultural diversity.

\section{Data}

The availability of survey data with information on the country of birth of the respondents and the respondents' parents is of crucial importance as we want to use the same definition of immigrants in both countries. While such data are rare in the world, both Germany and the Netherlands have such micro data for Turkish immigrants: for Germany the German SocioEconomic Panel (GSOEP) and for the Netherlands the Social Position and Use of Provisions (SPVA) survey.

For the selection of immigrants we use the following definitions: first generation immigrants are born outside the host country, while second generation immigrants are born in the host country and have at least one parents which is born outside the host country. ${ }^{5}$ In the remainder, we will use these definitions as much as possible. Appendix A contains a description of the two data sources, and a description of the selection of the Turkish immigrants from these data sources.

\footnotetext{
${ }^{5}$ Formally, the Dutch definition of first generation 'allochtonous' includes people born outside the Netherlands which have at least one parent born outside the Netherlands. This prevents children of diplomats from being categorized as 'allochtonous'.
} 


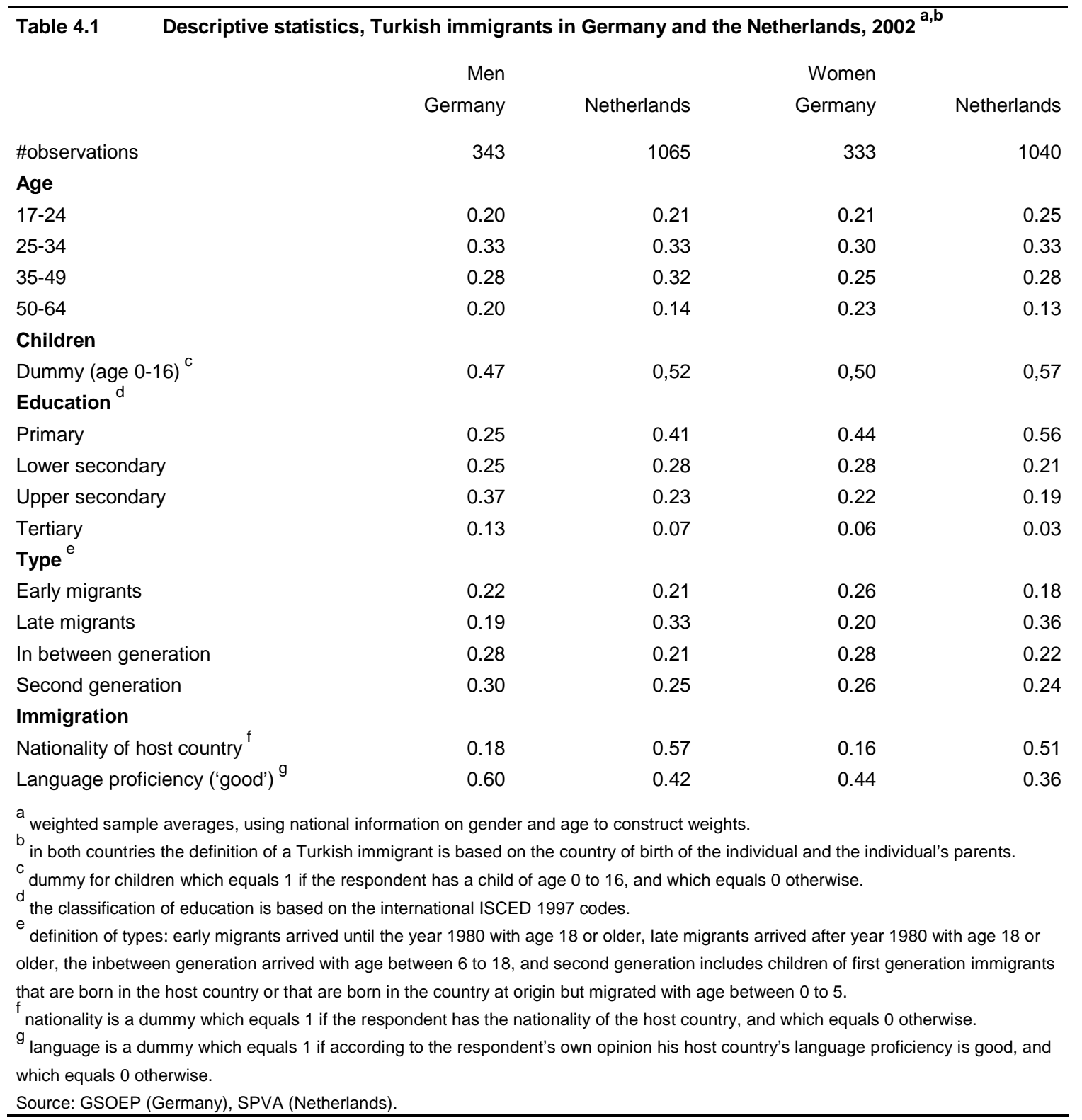

\subsection{Demographics and educational attainment}

The age structure of the Turkish immigrants is similar between the two countries (table 4.1).

The fact that the Netherlands received relatively more family reunification and family formation immigrants and Germany received relatively more asylum immigrants therefore has not affected the age structure of the group of Turkish immigrants in the year 2002 substantially. The incidence of having children seems to be different between the two countries.

Turkish immigrants in Germany have a higher level of education than their Dutch counterparts.

This is in line with the somewhat higher education level of the first generation immigrants in 
Germany (Akgündüz, 1993). Furthermore, the second generation may have been able to take advantage from the German education system which offers good opportunities to receive a higher secondary educational degree. The relatively low level of education of Turkish immigrants in the Netherlands may be a reason for a less favourable labour market position of Turkish immigrants in the Netherlands compared to Germany. Note however that the argument becomes however less obvious if one takes into account the level of education of natives: on average the Germans have a higher level of education than the Dutch. So although level of education is relatively low for Turkish immigrants in the Netherlands, this holds for Dutch natives compared to German natives as well (see Dagevos et al., 2006, Euwals et al., 2006).

\subsection{Reason for migration, naturalisation and language proficiency}

Although the goal of this study is to investigate the importance of individual characteristics related to immigration for the labour market position in a country, it is temping to compare the statistics between countries. To be clear on this issue: for the demographic variables the comparison may be reasonable, but for some of the immigration characteristics this may not be the case.

The reason for migration would preferably be classified in types like labour migration, family reunification, family formation and asylum migration. Both the German and the Dutch data do contain information on immigration motives. But unfortunately the variable is not comparable between the two countries as they are measured using different classifications. Therefore we use a classification on the basis of the variables 'year of migration' and 'age at migration' (see footnote e of table 4.1). The classification will not exactly represent the reason for migration, but at least there is some relation. The type 'early migrants' is likely to include many labour migrants for men and family reunification migrants for women, the type 'late migrants' is likely to include many family formation immigrants and asylum seekers (which we can not distinguish from each other), and the type 'in between generation' is likely to include many family reunification immigrants.

The relative size of the different immigration groups is in line with differences in immigration policy between both countries. The size of the group 'early migrants' is relatively large in Germany, which is in line with the fact that Germany allowed more Turkish labour immigrants to enter the country. And the size of the group 'late migrants' is relatively large in the Netherlands, which is in line with the fact that after the first oil crisis the Netherlands were less restrictive in terms of family reunification and family formation (section 3.1). The relatively low number of second generation immigrants in the Netherlands can be related to the initially lower number of labour migrants and their partners. 


\begin{tabular}{|c|c|c|c|c|}
\hline \multirow[t]{3}{*}{ Table 4.2} & Turkish imn & ts in Germany & Netherland & \\
\hline & Men & \multicolumn{3}{|c|}{ Women } \\
\hline & Germany & Netherlands & Germany & Netherlands \\
\hline \multicolumn{5}{|c|}{ Nationality of host country } \\
\hline Early migrants & 0.12 & 0.52 & 0.11 & 0.43 \\
\hline Late migrants & 0.21 & 0.46 & 0.11 & 0.33 \\
\hline In between generation & 0.22 & 0.60 & 0.16 & 0.60 \\
\hline Second generation & 0.20 & 0.73 & 0.27 & 0.78 \\
\hline \multicolumn{5}{|c|}{ Language proficiency ('good') } \\
\hline Early migrants & 0.29 & 0.14 & 0.17 & 0.06 \\
\hline Late migrants & 0.25 & 0.10 & 0.12 & 0.09 \\
\hline In between generation & 0.73 & 0.49 & 0.51 & 0.38 \\
\hline Second generation ${ }^{b}$ & 0.93 & 1.00 & 0.90 & 1.00 \\
\hline
\end{tabular}

The figures on having the nationality of the host country are in line with the naturalisation policies of the two countries (section 3.2): while in the Netherlands more than half of the Turkish immigrants have Dutch nationality, this is still true for a minority in Germany. The incidence of having the nationality of the host country varies substantially with the type of immigrant (upper panel of table 4.2). In particular many individuals of the 'in between' generation and the second generation have German/Dutch nationality. Nevertheless even for these groups the numbers of naturalised individuals is rather small in Germany.

The survey questions on language proficiency are self-reported on different scales for Germany and the Netherlands. As measurement of language proficiency is already difficult, it clear that figures are difficult to compare between countries (see Appendix B for details). Nevertheless the figures are in line with expectations based on the less restrictive immigration policy of the Netherlands, allowing for (low-skilled) family reunification and family formation immigration. Leaving the comparison between countries, the early and late first generation immigrants have a relatively unfavourable language proficiency. For the second generation almost all individuals are classified as having a good language proficiency, whereby for a part this may be due to the classification of individuals with missing data on language proficiency. But despite the potentially measurement error in this variable, the ranking of the type of immigrants on language proficiency is reasonable.

\section{$5 \quad$ Results}

This section investigates the relation between characteristics related to immigration and the labour market position of Turkish immigrants in Germany and the Netherlands. We focus on three measures that describe the labour market position: the employment rate (section 5.1), the 
tenured job rate (section 5.2), and the job prestige score (section 5.3). To quantify the relation we report descriptive statistics on the labour market position broken down by characteristics related to immigration. To correct for composition effects, we also report estimation results of regression techniques like linear regression and probit.

For a comparison between countries one should keep in mind that the differences in the labour market position of immigrants may not be related to immigration and integration. That is to say, differences between countries may occur for natives as well. A comparison of the labour market position of immigrants relative to natives is however beyond the scope of this study. ${ }^{6}$ In this study, we are interested in the role of characteristics related to immigration, like reason for migration, naturalisation and language proficiency. For natives such characteristics have no meaning, or at best a completely different meaning.

\subsection{Employment rate}

An obviously important measure for the position of immigrants on the labour market is the employment rate. On the one hand, a labour income guarantees that an immigrant contributes to the welfare state of a country in the form of paying taxes and social security contributions. On the other hand, it also guarantees that the take up of public expenditures is relatively low as there is no claim on welfare or social security benefits for unemployment and disability. ${ }^{7}$ In the remainder, we define the employment rate as the fraction of persons that works 12 hours or more per week. In both countries, marginal employment plays a considerable role. In Germany, labour income below a certain level is untaxed so that many students, housewives and retirees work a few hours per week. And in the Netherlands, the official employment statistics use a threshold of 12 hours per week to exclude marginal employment.

The employment rates vary substantially between different types of immigrants, and between the groups according to language proficiency and naturalisation (table 5.1). A direct comparison between the different groups should be interpreted with care as composition effects may hamper the results. This is particularly important as the different immigrant types are measured in different periods of their life course: the first generation immigrants are old on average, while the second generation immigrants are young. A direct comparison for men shows that in Germany the second generation performs relatively well as they have an employment rate that

\footnotetext{
${ }^{6}$ Dagevos et al. (2006a) and Euwals et al. (2006) investigate the labour market position of immigrants relative to natives.

${ }^{7}$ Unemployment is another obvious measure of the labour market position. We believe however it's meaning for a comparison between the countries is limited as the Netherlands has substantial hidden unemployment in the disability scheme.
} 
is larger than for first generation immigrants. For women, the employment rates are generally low whereby the second generation performs relatively well in both countries. Language proficiency is important for both genders as those that claim to have a good language proficiency have a high employment rate. For nationality the results are unclear: for Turkish men in Germany nationality seems to be unrelated to the employment rate.

Regression analysis corrects for composition effects and yields the marginal effect of the individual characteristics. The impact of demographic characteristics is in line with results known from the literature (table 5.2). Employment rates of prime age men are high in both countries, while for prime age women they are high in Germany and not in the Netherlands. ${ }^{8}$ Women with children have a low employment rate in Germany. The impact of children on the employment probability of women is small in the Netherlands, which is in line with the opportunities to work part-time and the relatively good child care facilities (at least, compared to West-Germany). Education increases the probability of being employed for almost al groups. ${ }^{9}$ The exception are however Turkish women in Germany, as education does not increase their employment probability (while from auxiliary regressions we know that education does increase the employment probability of native women). For the group of Turkish women in Germany prime age and being a second generation immigrant increases the employment probability. Most other characteristics do not matter, although for Turkish women in the Netherlands education does seem to lead to a higher probability of employment.

The impact of the characteristics related to immigration varies substantially between countries. In Germany, women of the second generation have a relatively large probability to be employed..$^{10}$ This holds for all women in this group, irrespective of their other individual characteristics. Nationality and language proficiency are not related to the employment probability. Men of the second generation do not have a larger probability to be employed in Germany, and also for them nationality and language proficiency does not matter. So the only way for the second generation men to improve their employment probability relative to the first generation men is by a higher level of education.

\footnotetext{
${ }^{8}$ As we use cross section data, the impact of age may include the impact of both age and cohort (which is related to immigrant type). The age effects of the young are largely based on the second generation and late first generation immigrants, while the age effects of the old are largely based on early first generation immigrants. The underlying assumption is that the age effects of the different types of immigrants are equal to each other.

${ }^{9}$ The impact of tertairy education for Turkish men in Germany is only just insignificant at a $10 \%$ significance level.

${ }^{10}$ Note that the second generation is young, and young women generally have a higher probability to be employed that older women. Statements on differences between immigrant types are therefore crucially dependent on a correct measurement of the impact of age (see footnote 8 ).
} 


\begin{tabular}{|c|c|c|c|c|}
\hline \multirow[t]{3}{*}{ Employment rat } & immigrant & ermany and th & lands, 2002 & \\
\hline & Men & \multicolumn{3}{|c|}{ Women } \\
\hline & Germany & Netherlands & Germany & Netherlands \\
\hline Total & 0.65 & 0.59 & 0.27 & 0.27 \\
\hline \multicolumn{5}{|l|}{ Type } \\
\hline Early migrants & 0.38 & 0.35 & 0.21 & 0.14 \\
\hline Late migrants & 0.64 & 0.72 & 0.19 & 0.21 \\
\hline In between generation & 0.83 & 0.65 & 0.27 & 0.36 \\
\hline Second generation & 0.70 & 0.56 & 0.41 & 0.38 \\
\hline \multicolumn{5}{|l|}{ Immigration } \\
\hline Nationality host country: no & 0.66 & 0.56 & 0.25 & 0.19 \\
\hline Nationality host country: yes & 0.64 & 0.61 & 0.38 & 0.35 \\
\hline Language proficiency 'good' : no & 0.58 & 0.58 & 0.21 & 0.20 \\
\hline Language proficiency 'good': yes & 0.70 & 0.61 & 0.36 & 0.40 \\
\hline $\begin{array}{l}\text { a } \text { Weighted sample averages. The em, } \\
4.1 \text { for the definitions of the variables. } \\
\text { Source: GSOEP (Germany), SPVA (N }\end{array}$ & is defined as & tion of persons th & hours or mor & eek. See table \\
\hline
\end{tabular}

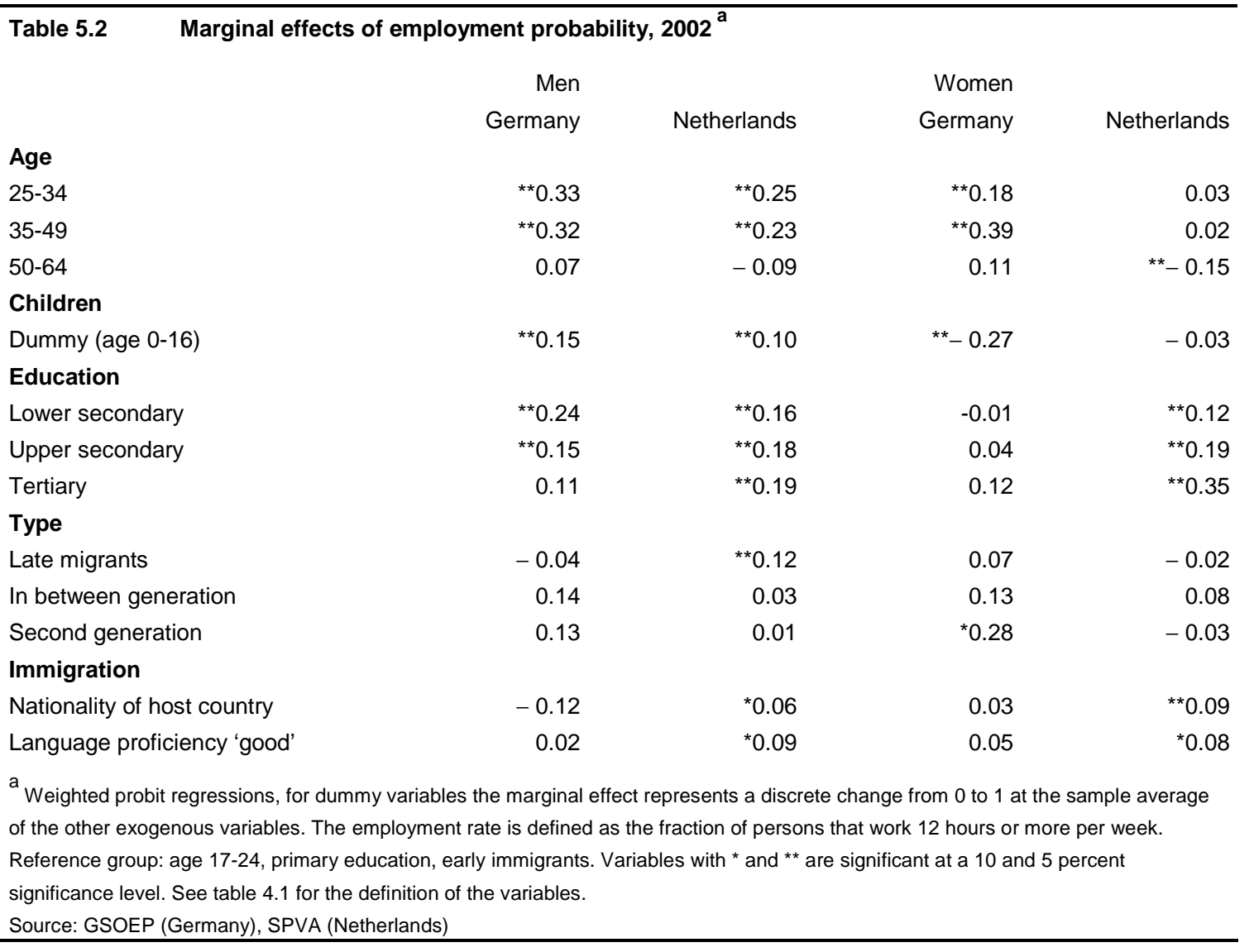


The Dutch results are very different from the German results. In the Netherlands, the second generation does not have a larger probability to be employed. Nevertheless, this group does have the possibility to improve its employment probability through a higher level of education, and possibly through naturalisation and language proficiency (which are at least positively related to employment). Second generation immigrants are more often naturalised and have a better language proficiency than first generation immigrants, which implies that on average the second generation has improved its employment probability relative to the first generation. ${ }^{11}$

\subsection{Tenured employment rate}

The incidence of having a tenured job is an important aspect of the labour market position. In both Germany and the Netherlands, the difference in employment protection between tenured and temporary employment is large. This difference is however slightly larger in the Netherlands (OECD, 2004). On the one hand, in the Netherlands employment protection of tenured employment is more strict due to longer notification periods and higher severance payments. On the other hand, the Dutch system offers slightly less employment protection for temporary jobs.

Tenured employment is known to be strongly related to age. While elderly workers almost exclusively hold tenured jobs, youngsters generally start their employment career with temporary jobs. This obviously affects the tenured job rates for the different types of immigrants (table 5.3). While the relatively old group of early first generation immigrants has a high tenured employment rate, the relatively young group of second generation immigrants have a low tenured employment rate. The composition effect may also affect the results on language proficiency and nationality. In Germany those who are naturalised have a low tenured employment rate, while in the Netherlands the same holds for those with a good language proficiency. These are likely to be caused by an age composition effect.

Regression analysis shows that age is indeed an important determinant of the tenured job employment rate (table 5.4). ${ }^{12}$ Individuals older than 25 have a statistically significant larger probability to have a tenured job. Furthermore, in Germany the level of education does not matter while in the Netherlands a higher level of education does lead to a larger probability to have a tenured job.

\footnotetext{
${ }^{11}$ About $80 \%$ of those with Dutch nationality actually have double citizenship. Of course this group dominates the results. Auxiliary regressions with a separate dummy for having only Dutch nationality yield results that are similar to the results presented in the paper. Future research may investigate this in more detail.

${ }^{12}$ Again the effect of age includes an age and cohort effect (see footnote 8). As temporary jobs are known to be fulfilled mainly by youngsters, the regression coefficient on age is likely to be dominated by the age effect.
} 


\begin{tabular}{|c|c|c|}
\hline \multirow[t]{2}{*}{ Tenured job rat } & Netherlan & \multirow[b]{2}{*}{ Netherlands } \\
\hline & Germany & \\
\hline Total & 0.86 & 0.76 \\
\hline \multicolumn{3}{|l|}{ Type } \\
\hline Early migrants & 1.00 & 0.92 \\
\hline Late migrants & 0.92 & 0.77 \\
\hline In between generation & 0.90 & 0.81 \\
\hline Second generation & 0.72 & 0.65 \\
\hline \multicolumn{3}{|l|}{ Immigration } \\
\hline Nationality host country: no & 0.88 & 0.73 \\
\hline Nationality host country: yes & 0.78 & 0.79 \\
\hline Language proficiency 'good' : no & 0.95 & 0.79 \\
\hline Language proficiency 'good': yes & 0.80 & 0.73 \\
\hline \multicolumn{3}{|c|}{$\begin{array}{l}\text { a Weighted sample averages. The tenured job rate is defined as the fraction of persons that has a tenured job among those that work } \\
\text { more than zero hours per week. See table } 4.1 \text { for the definitions of the variables. } \\
\text { Source: GSOEP (Germany), SPVA (Netherlands) }\end{array}$} \\
\hline
\end{tabular}

Table 5.4 Marginal effects of tenured job probabilities, $2002^{\mathrm{a}}$

Netherlands

Age

25-34

${ }^{* *} 0.19$

35-49

** $0.17 \quad$ **0.29

50-64

dropped $\quad * * 0.20$

Children

Men, with children (age 0-16)

Women, without children (age 0-16)

$\begin{array}{lr}0.02 & 0.06\end{array}$

Women, with children (age 0-16)

$-0.05$

$-0.01$

\section{Education}

Lower secondary

$\begin{array}{ll}0.01 & -0.05\end{array}$

Upper secondary

$\begin{array}{ll}-0.05 & { }^{* *} 0.10\end{array}$

Tertiary

0.08

Type

Late migrants

In between generation

$0.00 \quad * * 0.14$

Second generation

$\begin{array}{rr}\text { dropped }^{\mathrm{b}} & { }^{*}-0.10 \\ 0.02 & -0.03 \\ -0.01 & -0.05\end{array}$

Immigration

Nationality of host country

Language proficiency 'good'

$\begin{array}{rr}* *-0.13 & * * 0.09 \\ -0.08 & 0.00\end{array}$

a Weighted probit regressions, for dummy variables the marginal effect represents a discrete change from 0 to 1 at the sample average of the other exogenous variables. The tenured job rate is defined as the fraction of persons that has a tenured job among those that work more than zero hours per week. Reference groups: age 17-24, primary education, early immigrants. Variables with * and ${ }^{* *}$ are significant at 10 and 5 percent significance level. See table 4.1 for the definition of the variables.

${ }^{b}$ The reference group of early adult migrants have a tenured employment rate of $100 \%$ in Germany. We therefore choose the late migrants (adults) as a reference group for the German regression.

Source: GSOEP (Germany), SPVA (Netherlands) 
Despite the substantial differences between the different types of immigrants in table 5.3, the regression analysis shows that once corrected for the observed individual characteristics the differences between the types are not statistically significant. Only in the Netherlands, the group of late first generation immigrants have a lower probability to have a tenured job. In both countries, language proficiency is not related to tenured employment. But while in the Netherlands naturalisation is related positively to tenured employment, it is related negatively to tenured employment in Germany. An explanation for the result in Germany is that Turks which achieved a high level of individual assimilation - but for which recognition on the labour market stays behind - choose for naturalisation to achieve individual upward mobility and to improve their position within society (Diehl and Blom, 2003). The question is however why this does not occur in the Netherlands.

Can institutional differences between the two countries explain the different relation between naturalisation and the tenured job rate? Economic self-reliance plays a more important in the German immigration procedures (section 3.1), and temporary employment implies a risk of loosing the job and becoming economically dependent. This may lead to an incentive to naturalise for at least some workers with a temporary contract. And although the gains of naturalisation over a permanent residency permit seem small as a permanent permit offers substantial rights as well, these rights may be perceived as uncertain by the Turkish immigrants. So for Turks with a temporary job the larger gain from naturalisation in Germany compared to the Netherlands may be part of the explanation, whereby the incentive seems too small to explain a large part of the differences in outcomes between Germany and the Netherlands.

\section{$5.3 \quad$ ISEl job prestige score}

The ISEI job prestige score is based on the average level of education and the average level of earnings in an occupation. The score ranks worker occupations into a scale which varies from 10 (low) to 90 (high), see Ganzeboom and Treiman (2003). The results from the two scores are similar so that we only present the results for the ISEI job prestige score.

In both countries second generation immigrants, immigrants with a good language proficiency, and immigrants who are naturalised have a relatively high job prestige score (table 5.5). So the composition effect seems not to affect the results strongly, like it did for the employment and tenured employment rate. As however the immigration characteristics are related to each other, regression analysis needs to tell us which characteristics are more important. 


\begin{tabular}{|c|c|c|}
\hline \multirow[t]{2}{*}{ ISEI job prestig } & d the Net & \multirow[b]{2}{*}{ Netherlands } \\
\hline & Germany & \\
\hline Total & 33.9 & 37.5 \\
\hline \multicolumn{3}{|l|}{ Type } \\
\hline Early migrants & 30.7 & 36.1 \\
\hline Late migrants & 29.5 & 33.4 \\
\hline In between generation & 32.8 & 39.8 \\
\hline Second generation & 38.3 & 42.6 \\
\hline \multicolumn{3}{|l|}{ Immigration } \\
\hline Nationality host country: no & 32.9 & 34.0 \\
\hline Nationality host country: yes & 37.8 & 39.8 \\
\hline Language proficiency 'good' : no & 28.7 & 34.0 \\
\hline Language proficiency 'good': yes & 37.1 & 42.2 \\
\hline \multicolumn{3}{|c|}{$\begin{array}{l}\text { a Weighted sample averages. The ISEI job prestige score classifies jobs on a scale from } 10 \text { (low) to } 90 \text { (high) on the basis of the average } \\
\text { education level and income of those working in a job (Ganzeboom and Treiman, 2003). See table } 4.1 \text { for the definitions of the variables. } \\
\text { Source: GSOEP (Germany), SPVA (Netherlands) }\end{array}$} \\
\hline
\end{tabular}

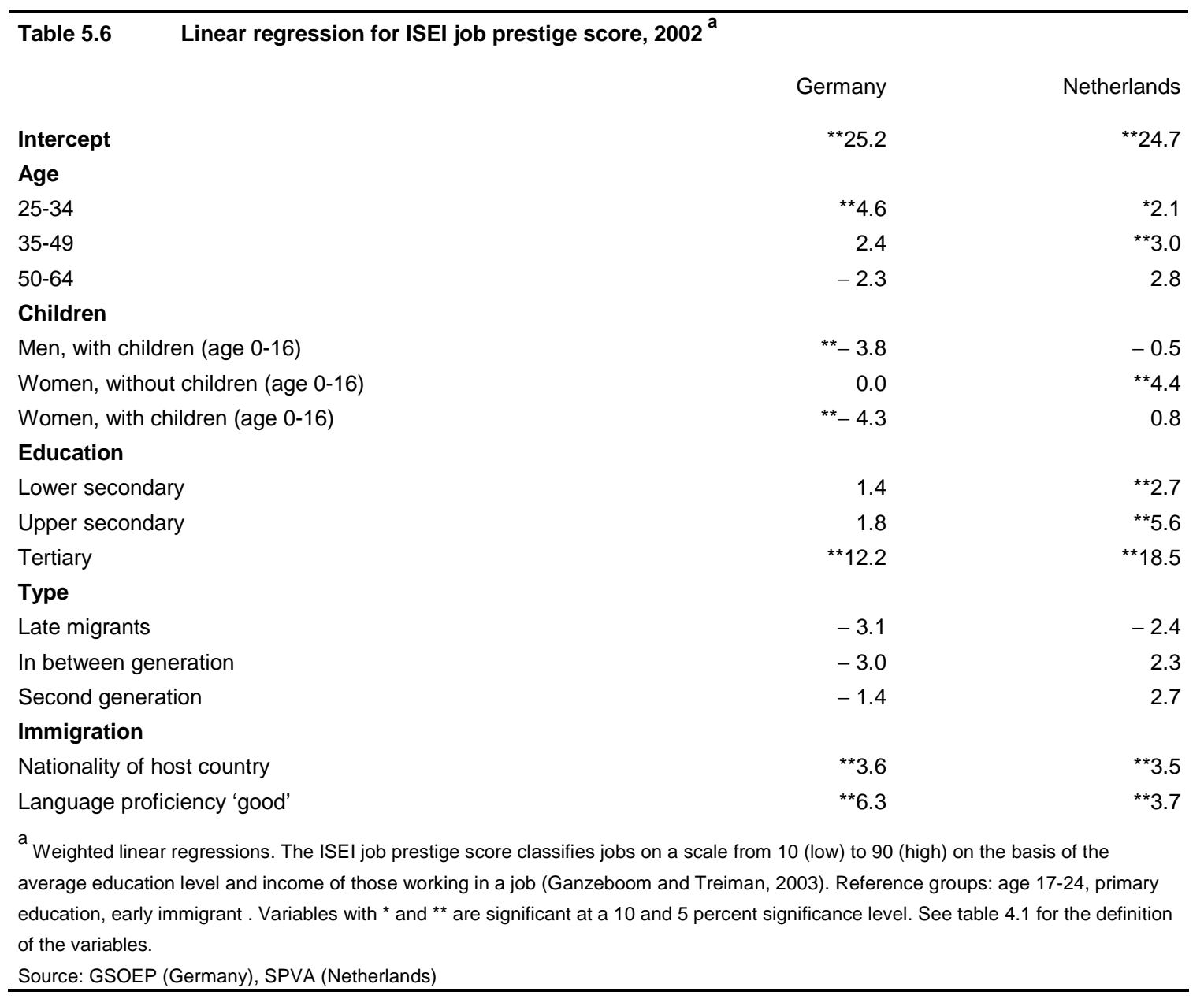


In both countries, prime age individuals have the highest job prestige score (table 5.6). Again note that the impact of age may contain both an age and a cohort effect, see footnote 8 . So the relatively low job prestige score of the oldest group may be a cohort effect, and younger cohorts may achieve higher job prestige score at the time they are old. In Germany both Turkish men and women with children have a lower score, while in the Netherlands the Turkish women without children do relatively well. The job prestige score increases with the level of education, but the return to education seems larger in the Netherlands. This is consistent with Dagevos $e t$ al. (2006a) and Euwals et al. (2006), which conclude that in the Netherlands highly educated Turkish immigrants perform less worse - relative to highly educated natives - than in Germany.

In both countries, second generation immigrants do not have job prestige scores that are significantly different from the scores of the other groups. Naturalisation and language proficiency are statistically significantly related to the job prestige score. So second generation immigrants seem to have improved their job prestige score relative to the first generation through a higher level of education, whereby this channel seems to be more important in the Netherlands. The second generation immigrants also have improved through the language channel, and possibly through the naturalisation channel as at least there is a positive relation between job prestige and nationality.

\section{$6 \quad$ Conclusion and discussion}

This study investigates the relevance of characteristics related to immigration for the labour market position of Turkish immigrants in Germany and the Netherlands. The characteristics include reason for migration, naturalisation and language proficiency. By comparing immigrants from the same country of origin, so with a similar social and cultural background, in two different host countries, we hope to learn about the importance of immigration and integration policies for the labour market position of immigrants. The comparison of Turkish immigrants in Germany and the Netherlands is interesting as they are the largest immigrant group in these countries. Moreover, both countries have micro data for this particular group. And while the countries have labour market institutions that are similar in many aspects, the immigration and integration policies are rather different.

We investigate the importance of the individual characteristics related to immigration for labour market outcomes like employment rates, tenured job rates and job prestige scores. The data are retrieved from the German Socio-Economic Panel 2002 and Dutch Social Position and Use of Provision Survey 2002. We use regression techniques to correct for composition effects of 
demographic and educational characteristics. The results show which individual characteristics are related to the labour market position, and which characteristics play a minor role.

What conclusions can we draw from the regression results? First, we find that educational attainment and language proficiency have a higher return in the Netherlands than in Germany. We find, for example, no evidence for a positive effect of educational attainment on the employment rate of Turkish women in Germany. Furthermore, language proficiency does not matter for the employment rate of both Turkish men and women in Germany (but it does matter for the job prestige score). Second, we find little evidence for a systematic difference in the labour market position between types of immigrants. In other words, conditional on the observed individual characteristics second generation immigrants do not perform better or worse than the first generation of labour migrants and their partners. This does not imply that there are no differences between types and generations: differences occur through other observed characteristics. Second generation immigrants have improved their labour market position relative to the first generation for an important part by improvements on educational attainment and language proficiency. This holds for both countries, whereby there are important differences between the countries due to differences in the return to education and language proficiency. Third, the relation between naturalisation and the labour market position differs between countries. For the Netherlands, naturalisation is related positively to employment, tenured employment and job prestige. Two explanations exist: either Turks with a relatively good labour market position choose for Dutch nationality, or Dutch nationality leads to a better labour market position. For Germany, naturalisation is related negatively to tenured employment. The contrasting results for the relation between nationality and tenured employment in Germany and the Netherlands may be explained partly by institutional differences. The gain from naturalisation for Turks with a temporary job is larger in Germany. Economic self-reliance plays a more important role in the German immigration procedures, and this may lead to a stronger incentive to naturalise for at least some workers with a temporary contract.

What are the policy implications? First, the most obvious policy implication is that educational policy and policy directed towards language proficiency are important. As second generation immigrants have a long period to receive the returns on human capital investments, such policies are particularly important for this group. In terms of educational policy, OECD (2006) urges both countries to implement policies to improve the schooling results of immigrant children. Second, the results show no systematic differences in the labour market position between types of immigrants per se. As there are nevertheless observable differences between the types, incentives and (self-)selection due to immigration policy matter. Selection on the basis of educational attainment will lead to a better labour market position of immigrants, but 
also incentives in acquiring language proficiency will have a positive effect. The Netherlands have implemented immigration and naturalisation policies that contain incentives in terms of language proficiency, while Germany recently has started to implement similar policies.

The policy implications of the results on naturalisation remain unclear. For the Netherlands, we find the relation between nationality and labour market position to be positive. Although this outcome may be interpreted as a signal in favour of the current Dutch practice, as at least the well integrated Turks become Dutch citizens, conclusions on the causal impact of naturalisation on labour market integration can not be drawn. For Germany, the relation between nationality and labour market position are mixed as there is a negative relation with tenured employment. Although institutional differences in the immigration and naturalisation rules may play a role for the impact of naturalisation, modesty on such conclusions is at its place as the literature reports too many contrasting results. Future research on more countries and other immigrant groups is necessary to find an answer on the role of naturalisation in the integration process. Furthermore, in particular longitudinal data on the individual development of naturalisation, integration and labour market attachment over time may prove to be valuable or even indispensable for future research.

\section{References}

Akgündüz, A, 1993, Labour Migration from Turkey to Western Europe (1960-1974), An Analytical Review, Capital and Class, Vol. 51, pp. 150-192.

Antecol, H, D. Cobb-Clark and S. Trejo, 2003, Immigration Policy and the Skills of Immigrants to Australia, Canada, and the United States, Journal of Human Resources, Vol. 38(1), pp. 192218.

Bevelander, P. and J. Veenman, 2006a, Naturalisation and Socioeconomic Integration: The Case of the Netherlands, IZA DP No. 2153.

Bevelander, P. and J. Veenman, 2006b, Naturalization and immigrants' employment integration in the Netherlands, Journal of International Migration and Integration, forthcoming.

Boeri, T., 2006, Migration Policy and the Welfare State, paper presented at the conference Reinventing the Welfare State, The Hague, April 27-28.

Borjas, G., 1985, Assimilation, Changes in Cohort Quality and the Earnings of immigrants, Journal of Labor Economics, Vol. 3(4), pp. 463-489. 
Bratsberg, B., J. Ragan and Z. Nasir, 2002, The Effect of Naturalisation on Wage Growth: A Panel Study of Young Male Immigrant, Journal of Labor Economics, Vol. 20(3), pp. 568-597.

Büchel, F. and Frick, J., 2004, Immigrants in the UK and in West Germany - Relative Income Positions, Income Portfolio, and Redistribution Effects, Journal of Population Economics, Vol. 17(3), pp. 553-581.

Büchel, F. and J. Frick, 2005, Immigrant's Economic Performance Across Europe - Does Immigration Policy Matter, Population Research and Policy Review, Vol. 24(2), pp. 175-212.

Carliner, G., 1980, Wages, Earnings and hours of First, Second and Thirs Generation American Males, Economic Inquiry, Vol. 18, pp. 87-102.

Chiswick, B., 1978, The Effect of americanization on the Earnings of foreign-born Men, journal of Political Economy, Vol. 86(5), pp. 897-921.

Chiswick, B. and P. Miller, 1995, The Endogeneity Between Language and Earnings: International Analyses, Journal of Labor Economics, Vol. 13 (2), pp. 245-287.

Chiswick, B., 1999, Are immigrants favourably selected? American Economic Review, Vol. 89(2), pp. 181-185.

Constant, A. and M. Schultz-Nielsen, 2004, Immigrant Selection and Earnings, in: Migrants, Work, and the Welfare State, T. Tranæs and K. F. Zimmermann (eds.), University Press of Southern Denmark, Odense, pp. 119-146.

Constant, A. and K. Zimmermann, 2005, Immigrant Performance and Selective Immigration Policy: A European Perspective, IZA DP No. 1715.

Dagevos, J., 2003, Employed Ethnic Minorities: Job Prestige, Temporary Employment and Mobility, in: J. Dagevos, M. Gijsberts and C. van Praag (eds) Report Ethnic Minorities 2003, pp. 231-256, SCP, The Hague (in Dutch).

Dagevos, J., R. Euwals, M. Gijsberts and H. Roodenburg, 2006a, Turken in Nederland en Duitsland: de arbeidsmarktpositie vergeleken, SCP and CPB, SCP Publication, 2006/23.

Dagevos, J., Hoff, S. and Soede, A., 2006b, Ethnic Minorities in Middle Class Positions, in: Social and Cultural Report 2006, pp. 119-152, SCP, The Hague (in Dutch) 
DeVoretz, D. and S. Pivnenko, 2006, The Economics of Canadian Citizenship, Journal of Immigration and Integration, forthcoming.

DeVoretz, D., H. Hinte and C. Werner, 2002, How Much Language is Enough? Some Immigrant Language Lessons from Canada and Germany, IZA DP No. 555.

Diehl, C. and M. Blohm, 2003, Rights or Identity? Naturalization Processes among Labor Migrants in Germany, International Migration Review, Vol. 37(1), pp. 133-162.

Dustmann, C., 1993, Earnings Adjustment of Temporary Migrants, Journal of Population Economics, Vol. 6, pp. 153-168.

Dustmann, C., 1994, Speaking Proficiency, Writing Proficiency and Earnings of Migrants, Journal of Population Economics, Vol. 7, pp. 133-156.

Dustmann, C., 1999, Temporary Migration, Human Capital and Language Proficiency, Scandinavian Journal of Economics, Vol. 101, pp. 297-314.

Dustmann, C. and A. van Soest, 2001, Language Proficiency and Earnings: Estimation with Misclassified Language Indicators, The Review of Economics and Statistics, Vol. 83(4), pp. 663-674.

Dustmann, C. and A. van Soest, 2002, Language and the Earnings of Immigrants, Industrial and Labour Relations Review, Vol. 55(3), pp. 473-492.

Dustmann, C. and F. Fabri, 2003, Language Proficiency and the Labour Market Performance of Immigrants in the UK, Economic Journal, Vol. 107, pp. 695-717.

Euwals, R., J. Dagevos, M. Gijsberts and H. Roodenburg, 2006, Immigration, Integration and the Labour Market: Evidence from First and Second Generation Turkish Immigrants in Germany and the Netherlands, CPB Discussion Paper No. 75.

Florax, R., T. de Graaff and B. Waldorf, 2005, A Spatial Economic Perspective on Language Acquisition: Segregation, Networking and Assimilation of immigrants, Environment and Planning A, Vol. 37(10), pp. 1877-1897.

Fougère, D. and M. Safi, 2006, The Effects of Naturalisation on Immigrants' Employment Probability, France 1968-1999, Mimeo. 
Gang, I. and K. Zimmermann, 2000, Is child like Parent? Educational Attainment and Ethnic Origin, Journal of Human Resources, Vol. 35(3), pp. 550-569.

Ganzeboom, H. and D. Treiman, 2003, Three Internationally Standardised Measures for Comparative Research on Occupational Status. In: J. Hoffmeyer-Zlotnik \& C. Wolf (Eds.), Advances in Cross-National Comparison. A European Working Book for Demographic and Socio-Economic Variables. New York, Kluwer Academic Press, pp. 159-193.

Grenier, G., 1984, The Effect of Language Characteristics on the Wages of Hispanic Males, Journal of Human Resources, Vol. 19(1), pp. 35-52.

Haisken-DeNew, J. and J. Frick, 2005, Desktop Companion to the German Socio-Economic Panel - Version 8, DIW, Berlin.

Kogan, I., 2003, Ex-Yugoslavs in the Austrian and Swedish labour markets: the significance of the period of migration and the effect of citizenship acquisition, Journal of Ethnic and Migration Studies, Vol. 29, pp. 595-622.

Lewin-Epstein, N., Semyonov, M., Kogan, I. and Wanner, R., 2003, Institutional Structure and Immigrant Integration: A Comparative Study of Immigrants' Labor Market Attainment in Canada and Israel, International Migration Review, Vol. 37, pp. 389-420.

McManus, W., W. Gould and F. Welch, 1983, Earnings of Hispanic Men: The Role of English Language Proficiency, Journal of Labor Economics, Vol. 1(2), pp. 101-130.

Model, S., Fisher, G. and Silberman, R., 1999, Black Carribeans in comparative perspective. Journal of Ethnic and Migration Studies, Vol. 25, pp. 187-212.

OECD, various years, Trends in International Migration - Annual Report, OECD.

Riphahn, R., 2003, Cohort Effects in the Educational Attainment of Second Generation Immigrants in Germany: An Analysis of Census Data, Journal of Population Economics, Vol. 16(4), pp. 711-737.

Shields, M. and S. Wheatly Price, 2002, The effect of language proficiency on the wages of immigrant men in England, Journal of Population Economics, Vol. 15, pp. 137-160. 
Tubergen, F. van, Maas, I. and Flap, H., 2004, The Economic Incorporation of Immigrants in 18 Western Societies: Origin, Destination, and Community Effects, American Sociological Review, Vol. 69, pp. 704-727.

van Ours, J. and J. Veenman, 2003, The Educational Attainment of Second Generation Immigrants in the Netherlands, Journal of Population Economics, Vol. 16(4), pp. 739-753.

van Ours, J. and J. Veenman, 2004, From Parent to Child: Early Labor Market Experiences of Second Generation Immigrants in the Netherlands, De Economist, Vol. 152(4), pp. 473-490.

van Ours, J. and J. Veenman, 2005, The Netherlands: Old Emigrants - Young Immigrant Country. In: Zimmermann, K. (ed.) European migration, What do we know?, CEPR-volume, Oxford University Press, pp. 173-197.

Yang, P., 1994, Explaining Immigrant Naturalization, International Migration Review, Vol. 28, pp. 449-477.

\section{Appendix A: Two data sources}

\section{The German Socio-Economic Panel}

The GSOEP is an ongoing panel survey with a yearly re-interview design, starting from the first year 1984 onwards. An important characteristic is the oversampling of foreigners: in 1984 the panel survey contained a sample of individuals in private households headed by someone with Turkish, Greek, Yugoslavian, Spanish or Italian citizenship, while in 1994/1995 an additional sample was added with individuals in private households in the former West Germany containing an individual who immigrated in the years from 1984 through 1994/1995 (excluding former East-Germans). Furthermore, the other parts of the panel survey contain some Turkish immigrants as well, although their number is small due to the small inclusion probability. As the yearly interview new household members are interviewed as well, the panel survey is refreshed automatically due to offspring and marriages. Furthermore, children leaving their parental home stay in the panel survey as well. The panel survey addresses themes like standard demographics, labour market and income position, education and subjective measures of life satisfaction and cultural attitudes. Furthermore, the sample of foreigners additionally addresses typical immigration themes like year and reason of immigration and language proficiency. The interviews were conducted in German or in the respondent's native language. ${ }^{13}$

\footnotetext{
${ }^{13}$ See Haisken-DeNew and Frick (2005) for more information on the GSOEP.
} 
Turks are the major immigrant group in Germany, and accordingly they are the largest foreigner group in the GSOEP. In the panel survey, they are identified on the basis of country of birth, the parents' country of birth and nationality. We use the information on nationality as well, as the information on the parents' country of birth is not always complete. We use weighting to correct for the potentially lower number of second generation immigrants (due to the partly incomplete information). All members of the household older than 16 years are interviewed. Our sample of Turkish immigrants contains observations on about 700 respondents.

\section{The Dutch Social Position and Use of Provisions Survey}

The SPVA survey is an important source of information on the position of ethnic minorities in the Netherlands. The survey is conducted every four years, starting from 1988 on and the last one being in 2002. The surveys provide information on the position of ethnic minorities on many socio-economic as well as social-cultural domains of integration. Among the themes addressed are the labour market and income position, education, language proficiency and cultural attitudes. On some of these topics, like language proficiency, the SPVA is the only source of information available in the Netherlands.

The SPVA contains information on the four largest minority groups in the Netherlands: Turks, Moroccans, Surinamese and Antilleans. The designated respondent is the head of the household (mostly male), who is interviewed through an extensive questionnaire. A selection of questions, including the ones we use, is also posed to the respondents spouse and offspring of 12 years and older. The interviews were conducted by interviewers from the own ethnic group if necessary, among Turks by bilingual interviewers. For each ethnic group the sample size is about 1000 households. We only include Turkish immigrants, and we are left with observations on about 2200 respondents.

\section{Appendix B: Measurement of language proficiency}

In the data sources of both countries, the survey questions on language proficiency are selfreported, and they are measured on different scales. This make the data on language proficiency difficult to compare between countries. Nevertheless, the data contains useful information on the impact of immigration characteristics within each of the countries. For Germany the information on language proficiency is important in explaining immigrant wages (see, for example, Dustmann and van Soest, 2001, 2002), while for the Netherlands the information is important in explaining job prestige (see Dagevos, 2003, and Dagevos et al., 2006b). 


\section{Question on language proficiency in German Socio-Economic Panel}

It necessarily easy for foreigners and immigrants to learn German when they come to Germany. But on the other hand, foreigners and immigrants who lived in Germany for an extended period of time might not also be able to speak the language of their native country of their parents as well any more. In your opinion, how well can you speak German?
1. Very well
2. Good
3. Fairly
4. Poorly
5. Not at all

In the Socio-Economic Panel, questions on language proficiency are measured on a five-point scale. In this study we use the information on German speaking (see above). The panel contains information on German writing and German understanding as well, but we do not use this information. We categorize the possible answers to the question on German speaking into two categories, whereby the first category aggregates the first two possible answers ('very well' and 'good') into one category. For many of the 'in between' and second generation immigrants (see table 4.1), the routing in the survey was such that they did not answer the questions on language proficiency. To prevent a substantial loss in the numbers of observations, we categorized them into the group with a good language proficiency (about $16 \%$ of the total sample).

\section{Question on language proficiency in Dutch Social Position and Use of Provisions Survey}

Do you have language problems when you have a conversation in Dutch?

Yes, very often/do not speak Dutch

6. Yes, sometimes

7. No, never

In the Social Position and Use of Provisions Survey, the question on language proficiency is measured on a three-point scale. We categorize the possible answers to the question into two categories, whereby the category ('no, never') is categorized as ('good') while the two remaining answers are aggregated into the category ('not good'). The Dutch data does not contain information on language proficiency of second generation immigrants. To prevent the loss of this generation in our analysis, we categorized their language proficiency as being good. 


\section{Interpretation of the data on language proficiency}

As stated above, the information on language proficiency is measured on different scales in the two countries. Furthermore, the information contains measurement error due to imputation of missing information again in both countries. This makes the information difficult to compare between countries, and also between some types of immigrants. The average language proficiency per group seems to be reasonable (see section 4.2), but nevertheless the information may contain substantial measurement error on the individual level. This problem does however not imply that the information is useless: in the regression analyses of section 5 measurement error leads to an underbound of true impact of language proficiency on the labour market position (see section 2.3). 